\title{
Opposite temperature effect on transport activity of KCC2/KCC4 and N(K)CCs in HEK-293 cells
}

Anna-Maria Hartmann ${ }^{1 *}$ and Hans Gerd Nothwang ${ }^{1,2}$

\begin{abstract}
Background: Cation chloride cotransporters play essential roles in many physiological processes such as volume regulation, transepithelial salt transport and setting the intracellular chloride concentration in neurons. They consist mainly of the inward transporters NCC, NKCC1, and NKCC2, and the outward transporters KCC1 to KCC4. To gain insight into regulatory and structure-function relationships, precise determination of their activity is required. Frequently, these analyses are performed in HEK-293 cells. Recently the activity of the inward transporters NKCC1 and NCC was shown to increase with temperature in these cells. However, the temperature effect on KCCs remains largely unknown.

Findings: Here, we determined the temperature effect on KCC2 and KCC4 transport activity in HEK-293 cells. Both transporters demonstrated significantly higher transport activity (2.5 fold for KCC2 and 3.3 fold for KCC4) after preincubation at room temperature compared to $37^{\circ} \mathrm{C}$.

Conclusions: These data identify a reciprocal temperature dependence of cation chloride inward and outward cotransporters in HEK-293 cells. Thus, lower temperature should be used for functional characterization of KCC2 and KCC4 and higher temperatures for N(K)CCs in heterologous mammalian expression systems. Furthermore, if this reciprocal effect also applies to neurons, the action of inhibitory neurotransmitters might be more affected by changes in temperature than previously thought.
\end{abstract}

\section{Background}

Cation chloride cotransporters (CCCs) are pivotal plasma membrane proteins for many physiological processes such as transepithelial salt transport, neuronal chloride homeostasis, and cell volume regulation $[1,2]$. Due to their essential functions, mutations of these transporters are associated with a variety of disorders such as deafness, renal dysfunction, seizures, and chronic pain, or are not compatible with life [1,2]. The mammalian genome codes for nine family members, seven of which are $\mathrm{Cl}^{-}$-transporters. The $\mathrm{Na}^{+}$-driven $\mathrm{NCC}, \mathrm{NKCC} 1$, and $\mathrm{NKCC} 2$ are $\mathrm{Cl}^{-}$-inward transporters, whereas the $\mathrm{K}^{+}$-driven family members $\mathrm{KCC} 1$ to $\mathrm{KCC} 4$ represent $\mathrm{Cl}^{-}$-outward transporters [1]. Due to their opposite transport direction, various mechanisms of reciprocal regulation of NKCCs and KCCs have been

\footnotetext{
* Correspondence: anna.maria.hartmann@uni-oldenburg.de

'Department of Neurogenetics, Institute for Biology and Environmental Sciences, Carl von Ossietzky University, Carl von Ossietzky Straße 9-11, 26129 Oldenburg, Germany

Full list of author information is available at the end of the article
}

reported. This includes opposite effects of phosphorylation, interaction partners such as WNK [3] and CIP1 $[4,5]$, or membrane rafts on the transport activity $[4,6]$.

The vital importance of CCCs has resulted in a high interest in regulatory mechanisms and structure-function relationships. Most studies addressing these issues have been performed in heterologous expression systems. HEK-293 cells represent the preferred mammalian expression system [4-10]. As a high transport activity is a prerequisite for functional studies, it is important to optimize the parameters in this cell line for functional analyses. A recent analysis of NKCCs in HEK-293 identified a marked increase in transport activity when shifting the cell line from room temperature (RT) to $37^{\circ} \mathrm{C}$ [11]. This observation is in agreement with previous NKCC flux measurements in red cells [12]. Furthermore, analyses of the $\mathrm{K}^{+}$-transport in red cells, which is likely mediated by KCC1 and KCC3 [13], revealed also a higher flux at elevated temperatures [14].

In light of these temperature dependent transport activity of various CCC family members, we investigated 
the temperature effect on $\mathrm{KCC} 2$ and $\mathrm{KCC} 4$ transport activity in HEK-293 cells. KCC2 is a neuronal isoform which is active under isotonic conditions [7] and localized in non-membrane rafts [6], whereas $\mathrm{KCC} 4$ resides in membrane rafts [15] and is active under hypotonic conditions [16]. Both transporters form one branch of $\mathrm{KCCs}$, whereas the other one is formed by $\mathrm{KCC} 1$ and KCC3 [1]. The activity of both transporters was significantly higher after a short preincubation at RT, contrasting the previously reported temperature effects on CCCs.

\section{Result}

Temperature-dependence of KCC2 and KCC4 transport activity in HEK-293 cells was determined after transient transfection by ${ }^{86} \mathrm{Rb}^{+}$flux measurements. All ${ }^{86} \mathrm{Rb}^{+}$ -uptake was sensitive to the KCC inhibitor furosemide (Figure 1). KCC2 transfected cells displayed a significant 1.5 fold increase in ${ }^{86} \mathrm{Rb}^{+}$uptake compared to mocktransfected control cells (Figure 1a, left part), when preincubated at $37^{\circ} \mathrm{C}$ prior flux measurements. When preincubated at RT for $30 \mathrm{~min}$, the activity was 2.3 fold increased compared to mock-transfected cells.

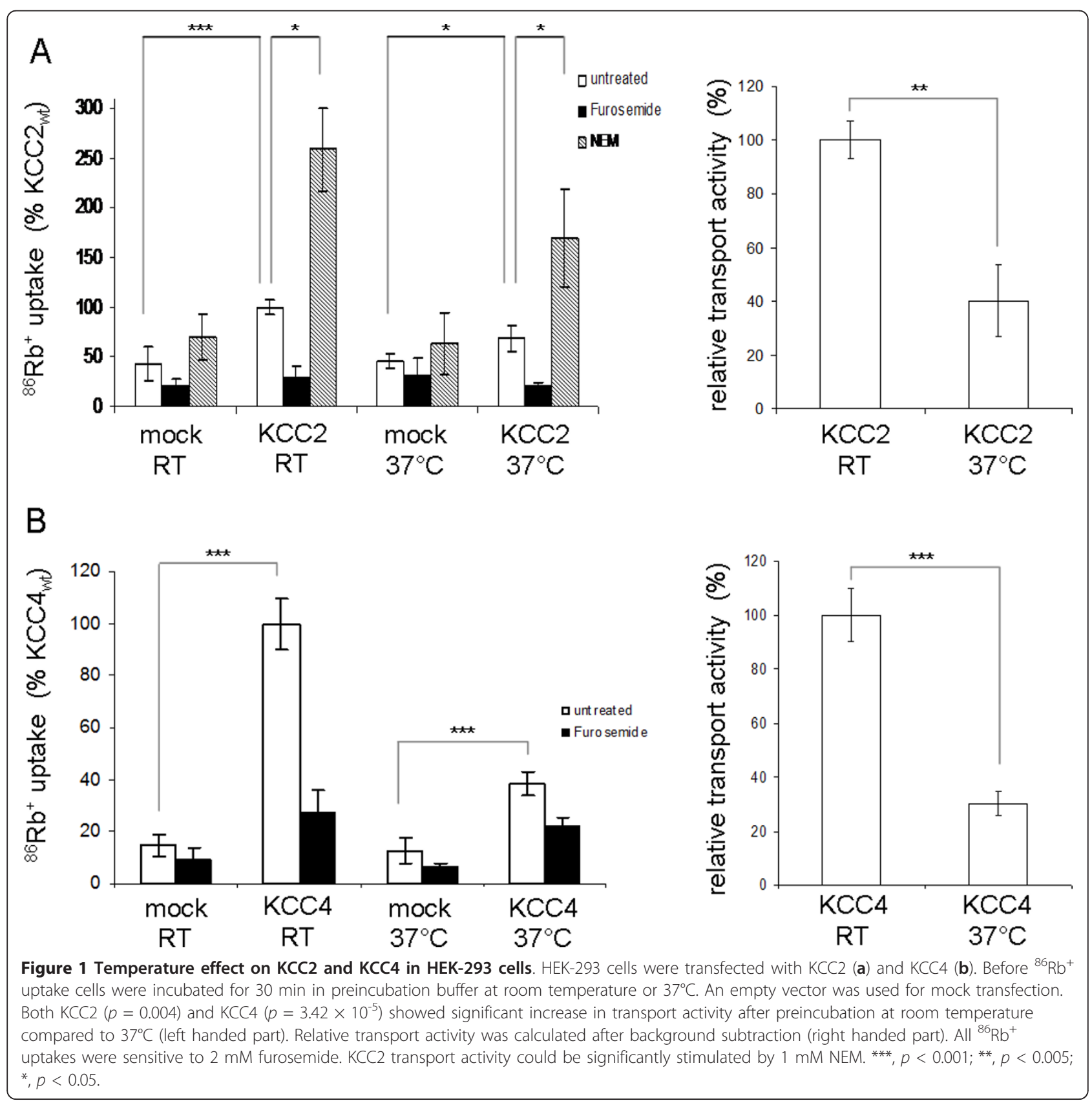


Importantly, the transport activity of $\mathrm{KCC} 2$ at RT was 2.5 fold increased compared to its activity at $37^{\circ} \mathrm{C}$ after background subtraction (Figure 1a, right part). This difference was highly significant $(p=0.004)$. To investigate whether $\mathrm{KCC} 2$ was still capable of a high transport activity at $37^{\circ} \mathrm{C}$, we stimulated its activity by different agents. Treatment with NEM, a known activator of KCC2 [17], resulted in a $\sim 2.5$ fold increased ${ }^{86} \mathrm{Rb}^{+}$ uptake, which was similar to the 2.6 fold stimulation observed at RT (Figure 1a). In addition, treatment with $7.5 \mu \mathrm{M}$ staurosporine, a protein kinase inhibitor, resulted in an 11 fold increase in KCC2 mediated ${ }^{86} \mathrm{Rb}^{+}$ uptake (data not shown). These data demonstrate that KCC2 is still able of a high transport activity after preincubation at $37^{\circ} \mathrm{C}$.

KCC4 transfected cells displayed a significant 3 fold increase in ${ }^{86} \mathrm{Rb}^{+}$-uptake at $37^{\circ} \mathrm{C}$ compared to mocktransfected cells (Figure 1b, left part). Similar to KCC2, preincubation at RT considerably increased the difference in the ${ }^{86} \mathrm{Rb}^{+}$-uptake between $\mathrm{KCC} 4$ transfected and mock transfected cells. We observed a 6.7 fold increase in ${ }^{86} \mathrm{Rb}^{+}$-flux in $\mathrm{KCC} 4$ expressing cells. After background subtraction, $\mathrm{KCC} 4$ had a significant 3.3 fold higher activity at $\mathrm{RT}$ compared to preincubation at $37^{\circ} \mathrm{C}$ $\left(p=3.4 \times 10^{-5}\right.$, right part). Taken together these data demonstrate a strong temperature-dependency of KCC2 and KCC4 transport activity in HEK-293 cells.

\section{Discussion}

The main finding of this study is that transport activity of KCC2 and KCC4 is significantly higher after $30 \mathrm{~min}$ preincubation at RT compared to $37^{\circ} \mathrm{C}$. The observed fold changes of 2.5 for KCC2 and 3.3 for KCC4 were in a similar range. This inverse correlation with temperature contrasts the increase in transport activity reported for $\mathrm{NKCC} 1$ and $\mathrm{NKCC} 2$ at $37^{\circ} \mathrm{C}$ compared to $\mathrm{RT}$ in the same heterologous expression system [11]. These data imply that $30-60 \mathrm{~min}$ preincubation at $\mathrm{RT}$ is the preferred condition for the analysis of $\mathrm{KCC} 2 / \mathrm{KCC} 4$ and $37^{\circ}$ C for NKCCs in the widely used HEK-293 cells in order to obtain high transport activity.

Whether our findings for KCC2 and KCC4 can be extended to the other branch of KCCs, i.e. KCC1 and KCC3 remains to be elucidated. Previous studies in red cells have indicated that KCC1 and KCC3 activity increased with elevated temperatures $[13,14]$. This opposite effect could either reflect differences in the two KCC branches or a cell-type specific modulation of KCCs by temperature. To answer this issue requires insight into the underlying mechanism. Both for KCCs and NKCCs, the effect occurs within 30-60 min and various scenarios could be envisaged. i) A temperature-dependent modification such as phosphorylation might occur [11]. An increased activity of the known CCC regulators WNK and SPAK at $37^{\circ} \mathrm{C}$ would result in an increase in the transport activity of NKCCs and a decrease in activity of KCCs $[18,19]$. Both WNK1 and SPAK are present in HEK-293 cells [20]. It might therefore be worthwhile to investigate the contribution of these kinases on the observed temperature effects. ii) The temperature might affect folding and trafficking of newly synthesized transporters, their structural configuration in the plasma membrane, or reduce endocytosis of plasma membrane residing transporters [21]. These mechanisms, however, should be rather independent of the cell-type analysed. iii) CCCs are secondary active transporters which depend on the $\mathrm{Na}^{+} / \mathrm{K}^{+}$-ATPase [1]. Therefore, altered activity of this pump would influence CCC-mediated transport. Indeed, ablation of the $\mathrm{Na}^{+} / \mathrm{K}^{+}$-ATPase subunit Atp1a2 results in increased neuronal $[\mathrm{Cl}]_{\mathrm{i}}[22]$. Elevated preincubation temperatures in buffers containing no nutrients might result in a compromised metabolic state of the cell, resulting in decreased $\mathrm{Na}^{+} / \mathrm{K}^{+}$-ATPase activity. However, we consider this explanation unlikely as altered activity of $\mathrm{Na}^{+} / \mathrm{K}^{+}$-ATPase would influence KCCs and $\mathrm{N}$ (K)CCs in the same direction. We also blocked the $\mathrm{Na}$ ${ }^{+} / \mathrm{K}^{+}$-ATPase throughout the experiments by adding ouabain prior exposure to different temperatures. In addition, the observed increase of NKCC1 activity after a 60 min incubation at $37^{\circ} \mathrm{C}$ compared to RT [11] strongly argues against a compromised metabolism in HEK-293 cells after preincubation for up to $1 \mathrm{~h}$ at elevated temperatures. In line with this, our data demonstrate that KCC2 activity can be still strongly stimulated by staurosporine or NEM after preincubation at $37^{\circ} \mathrm{C}$.

The observed temperature effect might have important biomedical implications for the analyses of inhibitory neurotransmission in neurons. The action of the two major inhibitory neurotransmitters GABA and glycine in neurons depends on the intracellular chloride concentration $[\mathrm{Cl}]_{\mathrm{i}}[2,23]$, as their receptors represent ligandgated chloride channels. A high $[\mathrm{Cl}]_{\mathrm{i}}$ hence results in depolarization, whereas low $[\mathrm{Cl}]_{\mathrm{i}}$ causes hyperpolarization. Since the electrochemical equilibrium for chloride is close to the resting membrane potential, subtle reciprocal changes in the transport activity of NKCC1 and $\mathrm{KCC} 2$ and consequently in $[\mathrm{Cl}]_{\mathrm{i}}$ can inverse the action of these neurotransmitters.

\section{Conclusion}

In summary, our data demonstrate that $\mathrm{KCC} 2$ and KCC4 transport activity is strongly influenced by temperature in heterologous mammalian expression systems. A short preincubation $(30 \mathrm{~min})$ at room temperature is therefore recommended to obtain high transport activity. In addition, the opposite effect of temperature on $\mathrm{KCC} 2 / \mathrm{KCC} 4$ and NKCCs adds another facet to the reciprocal regulation of these two branches 
of the cation chloride cotransporter gene family. Futures studies have to address whether the temperature sensitivity holds true for in vivo analyses as well.

\section{Materials and methods \\ Plasmid constructs}

We used previously reported pCDNA3.1 expression vectors with the open reading frames of rat KCC2b (GenBank accession no. NM_134363) and mouse KCC4 (GenBank accession no. NM_011390) [8].

\section{Determination of $\mathrm{K}^{+}-\mathrm{Cl}^{-}$cotransport}

Transport activity was determined by measuring uptake of ${ }^{86} \mathrm{Rb}^{+}$(PerkinElmer Life Sciences) in HEK293 cells. Cells were cultured in Dulbecco's Modified Eagle Medium (Invitrogen, Darmstadt, Germany) and transfected using TurboFect (Fermentas, St. LeonRoth, Germany). Cells were harvested $48 \mathrm{~h}$ after transfection and transferred into poly-L-lysine-coated wells of a 6-well-culture dish and incubated for $3 \mathrm{~h}$. After removal of the medium, cells were incubated in $1 \mathrm{ml}$ preincubation buffer (100 mM N-methyl-D-glucaminechloride, $5 \mathrm{mM} \mathrm{KCl}, 2 \mathrm{mM} \mathrm{CaCl} 2,0.8 \mathrm{mM} \mathrm{MgSO}_{4}, 5$ $\mathrm{mM}$ glucose, $5 \mathrm{mM}$ HEPES, pH 7.4, $0.1 \mathrm{mM}$ oubain) for $30 \mathrm{~min}$ at $\mathrm{RT}$ or $37^{\circ} \mathrm{C}$. Treatment with $7.5 \mu \mathrm{M}$ staurosporine for $30 \mathrm{~min}, 1 \mathrm{mM} \mathrm{NEM}$ or $2 \mathrm{mM}$ fouresemide for $15 \mathrm{~min}$ occurred in the preincubation buffer. A 10 min uptake period followed in preincubation buffer supplemented with $1 \mu \mathrm{Ci} / \mathrm{ml}^{86} \mathrm{Rb}^{+}$at $\mathrm{RT}$. At the end of the uptake period, cells were washed three times in $1 \mathrm{ml}$ ice-cold preincubation buffer to remove extracellular tracer. Cells were lysed in $500 \mu \mathrm{l} 0.25 \mathrm{M}$ $\mathrm{NaOH}$ for $1 \mathrm{~h}$ and then neutralized with $250 \mu \mathrm{l}$ pure acetic acid. ${ }^{86} \mathrm{Rb}^{+}$uptake was assayed by Cerenkov radiation, and the protein amount was determined by BCA (Thermo Fisher Scientific, Bonn, Germany). In addition, expression of the respective construct was determined for each flux measurement by immunoblot analysis. Two biological and three technical replicas were performed for each experiment. Data are given as mean \pm standard error deviation. Significant differences between the groups were analyzed by a Student's $t$-test.

\section{Acknowledgements \\ We gratefully acknowledge Martina Reents for expert technical support. This work was supported by grants from the Deutsche Forschungsgemeinschaft} (No428/2-3 to H.G.N.).

\section{Author details}

${ }^{1}$ Department of Neurogenetics, Institute for Biology and Environmental Sciences, Carl von Ossietzky University, Carl von Ossietzky Straße 9-11, 26129 Oldenburg, Germany. ${ }^{2}$ Research Center Neurosensory Science, University of Oldenburg, 26129 Oldenburg, Germany.

\section{Authors' contributions}

$\mathrm{AMH}$ carried out the experiments and wrote the manuscript. $\mathrm{AMH}$ and $\mathrm{HGN}$ designed the experiments. HGN helped to draft the manuscript. Both authors read and approved the final manuscript.

\section{Competing interests}

The authors declare that they have no competing interests.

Received: 21 September 2011 Accepted: 9 December 2011 Published: 9 December 2011

\section{References}

1. Gamba G: Molecular physiology and pathophysiology of electroneutral cation-chloride cotransporters. Physiol Rev 2005, 85:423-493.

2. Blaesse $P$, Airaksinen MS, Rivera C, Kaila K: Cation-chloride cotransporters and neuronal function. Neuron 2009, 61:820-838.

3. de Los HP, Kahle KT, Rinehart J, Bobadilla NA, Vazquez N, San Cristobal P: WNK3 bypasses the tonicity requirement for $\mathrm{K}-\mathrm{Cl}$ cotransporter activation via a phosphatase-dependent pathway. Proc Natl Acad Sci USA 2006, 103:1976-1981.

4. Caron L, Rousseau F, Gagnon E, Isenring P: Cloning and functional characterization of a cation-Cl- cotransporter-interacting protein. $J$ Biol Chem 2000, 275:32027-32036.

5. Wenz M, Hartmann AM, Friauf E, Nothwang HG: CIP1 is an activator of the $\mathrm{K}+-\mathrm{Cl}$ - cotransporter KCC2. Biochem Biophys Res Commun 2009, 381:388-392.

6. Hartmann AM, Blaesse P, Kranz T, Wenz M, Schindler J, Kaila K: Opposite effect of membrane raft perturbation on transport activity of KCC2 and NKCC1. J Neurochem 2009, 111:321-331.

7. Payne JA: Functional characterization of the neuronal-specific $\mathrm{K}-\mathrm{Cl}$ cotransporter: implications for [K+]o regulation. Am J Physiol 1997, 273: C1516-C1525.

8. Hartmann AM, Wenz M, Mercado A, Storger C, Mount DB, Friauf E: Differences in the large extracellular loop between the $\mathrm{K}(+)-\mathrm{Cl}(-)$ cotransporters KCC2 and KCC4. J Biol Chem 2010, 285:23994-24002.

9. Delpire E, Days E, Lewis LM, Mi D, Kim K, Lindsley CW: Small-molecule screen identifies inhibitors of the neuronal K-Cl cotransporter KCC2. Proc Natl Acad Sci USA 2009, 106:5383-5388.

10. Uvarov P, Ludwig A, Markkanen M, Soni S, Hubner CA, Rivera C. Coexpression and heteromerization of two neuronal $\mathrm{K}-\mathrm{Cl}$ cotransporter isoforms in neonatal brain. J Biol Chem 2009, 284:13696-13704.

11. Hannemann A, Flatman PW: Phosphorylation and transport in the Na-K$2 \mathrm{Cl}$ cotransporters, NKCC1 and NKCC2A, compared in HEK-293 cells. PLoS One 2011, 6:e17992.

12. Stewart GW, Ellory JC, Klein RA: Increased human red cell cation passive permeability below $12^{\circ} \mathrm{C}$. Nature $1983,286: 403-404$.

13. Lauf PK, Zhang J, Delpire E, Fyffe REW, Mount DB, Adragna NC: K-Cl cotransport: immuncytochemical and functional evidences for more than one $\mathrm{KCC}$ isoform in high $\mathrm{K}$ and low $\mathrm{K}$ sheep erythrocytes. Comp Biochem Physiol A 2001, 130:499-509.

14. Jennings $M L$, Al-Rohil $\mathrm{N}$ : Kinetics of activation and inactivation of swelling-stimulated $\mathrm{K}^{+} / \mathrm{Cl}^{-}$transport. J Gen Physiol 1990, 95:1021-1040.

15. Fujii T, Takahashi Y, Itomi Y, Fujita K, Morii M, Tabuchi Y: K+-Clcotransporter-3a up-regulates $\mathrm{Na}+, \mathrm{K}+$-ATPase in lipid rafts of gastric luminal parietal cells. J Biol Chem 2008, 283:6869-6877.

16. Mercado A, Song L, Vazquez N, Mount DB, Gamba G: Functional comparison of the $\mathrm{K}+-\mathrm{Cl}-$ cotransporters $\mathrm{KCC} 1$ and KCC4. J Biol Chem 2000, 275:30326-30334

17. Adragna NC, Di Fulvio M, Lauf PK: Regulation of K-Cl cotransport: from function to genes. J Membr Biol 2004, 201:109-137.

18. Gagnon KB, England R, Delpire E: Volume sensitivity of cation chloride cotransporters is modulated by the interaction of two kinases; Ste20related proline-alanine-rich kinase WNK4. Am J Physiol Cell Physiol 2006, 290:C134-C142.

19. Kahle KT, Rinehart J, De Los Heros HP, Louvi A, Meade P, Vazquez N: WNK3 modulates transport of $\mathrm{Cl}$ - in and out cells: implications for control of cell volume and neuronal excitability. Proc Natl Acad Sci USA 2005, 102:16783-16788.

20. Rinehart J, Makismova YD, Tanis JE, Stone $K L$, Hodson AA, Zhang J, Risinger M, Pan W, Wu D, Colangelo CM, Forbush B, Joiner CH, Gulcicek EE, 
Gallagher PG, Lifton RP: Sites of phosphorylation that control K-Cl cotransporter activity. Cell 2009, 138:525-536.

21. Kuismanen E, Saraste J: Low temperature-induced transport blocks as tools to manipulate membrane traffic. Methods Cell Biol 1989, 32:257-274.

22. Ikeda K, Onimaru H, Yamada J, Inoue K, Ueno S, Onaka TM, Toyoda H, Arata A, Ishikawa T, Taketo MM, Fukuda A, Kawakami K: Malfunction of respiratory -related neuronal activity in $\mathrm{Na}^{+}, \mathrm{K}^{+}$-ATPase a2 subunitdeficient mice is attributable to abnormal $\mathrm{Cl}$ - homeostasis in brainstem neuron. J Neurosci 2004, 24:10693-10701.

23. Ben-Ari Y: Excitatory actions of GABA during development: the nature of the nurture. Nat Rev Neurosci 2002, 3:728-739.

doi:10.1186/1756-0500-4-526

Cite this article as: Hartmann and Nothwang: Opposite temperature

effect on transport activity of KCC2/KCC4 and N(K)CCs in HEK-293 cells.

BMC Research Notes 2011 4:526.

\section{Submit your next manuscript to BioMed Central} and take full advantage of:

- Convenient online submission

- Thorough peer review

- No space constraints or color figure charges

- Immediate publication on acceptance

- Inclusion in PubMed, CAS, Scopus and Google Scholar

- Research which is freely available for redistribution

Submit your manuscript at www.biomedcentral.com/submit 